\title{
Screening embryos may lead to stigma
}

$\mathrm{M}$ ost people who opt for in vitro fertilization have trouble conceiving, though some women without fertility problems make the choice to screen out embryos that carry heritable genetic mutations. As advancing technologies allow for the detection of subtler mutations, including predisposition to late-onset diseases that can be treated, some people are wondering if creating a list of "serious" conditions to be avoided may have unintended consequences.

Screening embryos in a petri dish for a genetic mutation - and choosing one without it for the in vitro fertilization procedure - is called preimplantation genetic diagnosis, or PGD for short. It has been used for years to screen for devastating illnesses with no cure, such as Huntington disease. Now the test is also able to detect predispositions to conditions such as breast and colon cancer, which may not occur until late in life, if at all, and can often be treated.

"You don't want to delegitimize requests for those tests, but you can still have a life worth living before the onset of those conditions," says Timothy Krahn, a research associate (novel tech ethics) in the Faculty of Medicine at Dalhousie University in Halifax, Nova Scotia. "We need to make sure there are adequate social services and support for the types of conditions for which we are screening."

In the United Kingdom, regulations state that PGD is to be used only when there is risk of a "serious" genetic condition, though regulators fail to define what "serious" means in this context, Krahn noted in a recent paper (Med Law Rev 2011;19:157-91). In Canada and the United states, the procedure is hardly regulated at all. In other countries - including Switzerland, China, Ireland and Austria — it is prohibited.

The appropriateness of using PGD should take into consideration several factors, Krahn suggested in his paper, including the views of people with the conditions being screened, the likely

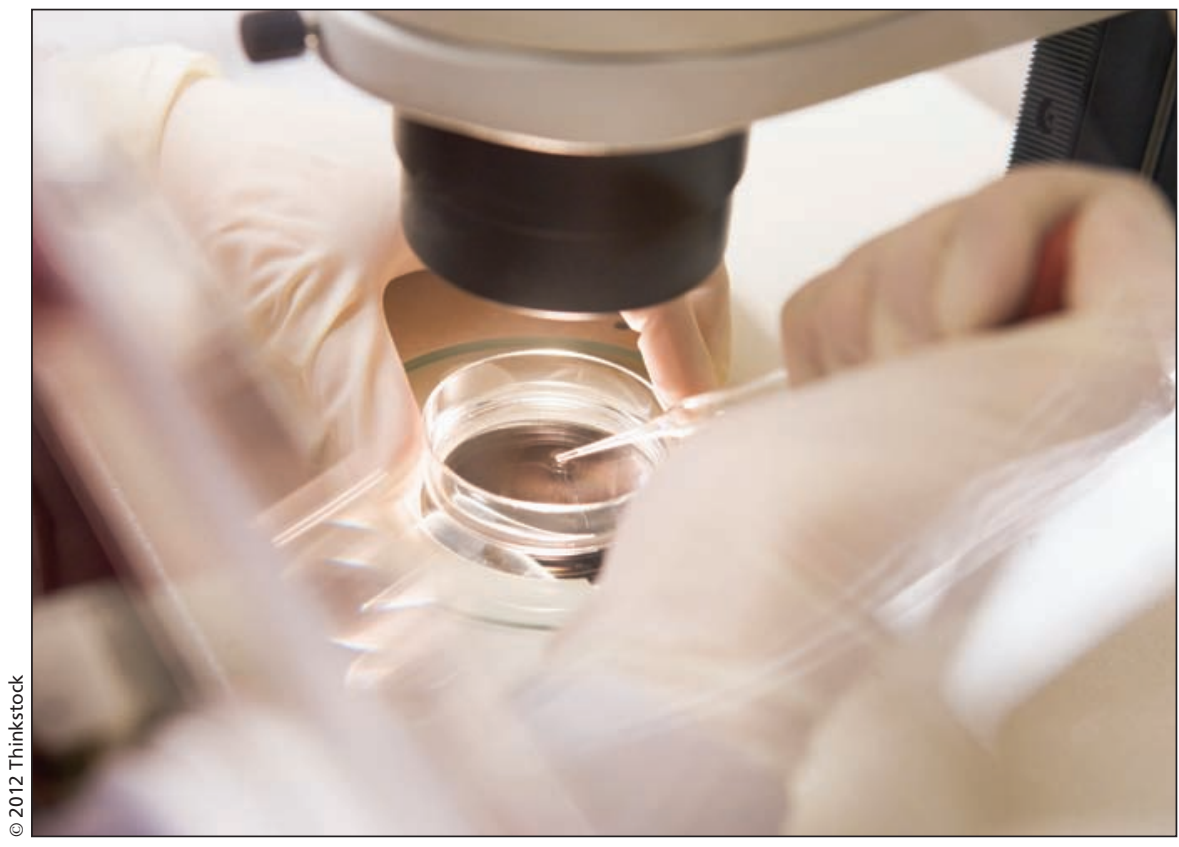

Preimplantation genetic diagnosis has been used for years to screen for devastating illnesses with no cure, such as Huntington disease, but now the test is also able to detect predispositions to conditions such as breast and colon cancer.

degree of suffering, availability of effective therapies, the speed of degeneration caused by the condition, the extent of intellectual impairment and whether there are social supports available.

Using Down syndrome as a test case, Krahn wrote that including it in PGD was debatable, if not problematic, because social supports are available, intellectual impairment is not as severe as people think, and health and lifespans of people with the condition have improved dramatically over the years.

"As such, by allowing access to PGD testing for only 'serious genetic conditions' and labeling Down's syndrome as one such condition, in effect the current regulatory system in this instance risks participating in a form of social discrimination, possibly compounding forces of stigma, prejudice, and general misinformation about the capacities and quality of life possible for persons living with Down's syndrome," the paper concludes.

However, the solutions to ethical dilemmas raised by PGD don't lie in restricting access to particular tests, says Krahn, but rather in creating policies and services to ensure women have the freedom to give birth to children with genetic conditions the medical community may consider inherently undesirable. Otherwise women may someday be viewed as selfish for burdening society with children who develop conditions that could have been tested for during the insemination procedure.

"The moral harms at stake for PGD are things that having a list to restrict access to tests won't prevent. The broader values that are being compromised are about women's reproductive autonomy and stigmatizing the lives of people with conditions on the list," says Krahn. "Most of the discussions on ethics are on restricting access. I think the bigger ethical issue is what we are doing to create a tolerant society where women have the choice to have a child with a disability."

Of course, the vast majority of people who undergo in vitro fertilization do so because they really want children - 
healthy children, sure, but not "designer babies" with perfect genes. Most patients who add PGD to the process aren't weeding out embryos for questionable reasons. "We haven't had people make PGD requests for anything that would raise eyebrows," says Tara Clancy, a consultant genetic counsellor and lecturer in medical genetics at the University of Manchester in the UK.

In the UK, the scope of PGD is generally patient-led, and most people test for conditions that would be extremely burdensome to the child. If the push for PGD came from the government instead of patients, though, that might muddy the ethical waters surrounding the procedure. "Where it gets more difficult is if it's offered as a national screening program," says Clancy. "It can feel as if there is some implicit 'rightness' to it."

Whether it is "right" to screen for particular conditions, such as lateonset inherited cancers, raises a number of ethical issues, Clancy has suggested (Fam Cancer 2010;9:9-14). One such issue is "whether reduced penetrance and/or the availability of treatment mean that these are not serious (enough) conditions to warrant tests prior to/during pregnancy or to justify termination of pregnancy," wrote Clancy. "However, attempts to reach a consensus on what counts as a serious (enough) condition in the context of PND [prenatal diagnosis] and PGD have been unsuccessful. Such a definition may anyway be unhelpful if it cannot also take into account, for example, the woman's/couple's awareness and experience of the condition and the impact of the condition on affected individuals and their families." Roger Collier, CMAJ

CMAJ 2012. DOI:10.1503/cmaj.109-4177

Editor's note: Eleventh of a multipart series on genetic testing.

Part 1: Separating hype from reality in the era of the affordable genome (www.cmaj.ca/lookup/doi/10.1503/cmaj.109-4143).

Part 2: Popping the genetics bubble

(www.cmaj.ca/lookup/doi/10.1503/cmaj.109-4142).

Part 3: Who should hold the keys to your DNA?

(www.cmaj.ca/lookup/doi/10.1503/cmaj.109-4141).

Part 4: A race-based detour to personalized medicine (www.cmaj.ca/lookup/doi/10.1503/cmaj.109-4133).

Part 5: Race and genetics in the doctor's office (www.cmaj.ca/lookup/doi/10.1503/cmaj.109-4134).

Part 6: Predisposed to risk but not change (www.cmaj.ca/lookup/doi/10.1503/cmaj.109-4157).

Part 7: Unhealthy behaviours influenced by genes and environment (www.cmaj.ca/lookup/doi/10.1503/cmaj.109-4162).

Part 8: Young women with breast cancer genes face tough choices (www.cmaj.ca/lookup/doi/10.1503/cmaj.109-4168).

Part 9: The downside of genetic screening (www.cmaj.ca/lookup/doi/10.1503/cmaj.109-4169).

Part 10: Surge in Down syndrome prenatal testing anticipated (www.cmaj.ca/lookup/doi/10.1503/cmaj.109-4170). 